\title{
Kwestia wielokulturowości Czarnogóry wobec problemu integracji państwa ${ }^{1}$
}

Poczucie stabilności i bezpieczeństwa, dające jednostkom społecznym możliwość funkcjonowania w środowisku, sprzyjające realizacji ich celów i podstawowych założeń, stanowi niezwykle istotna wartość. Jednak w obliczu zagrożeń współczesnego świata, których skala i źródła zyskują coraz to nowszy i niespotykany dotąd wymiar, trudno jest mówić o ich całkowitej gwarancji. Zapewnienie powyższych dwóch atutów wydaje się więc stanowić wartość nadrzędna, być czynnikiem decydującym o przetrwaniu materialnym, stabilnym rozwoju państw i ich obywateli. Wśród wielu definicji bezpieczeństwa funkcjonuje wręcz odrębna kategoria bezpieczeństwa społecznego (societal security), autorstwa Barry'ego Buzana. Przedstawiciel tzw. szkoły kopenhaskiej dowodzi $\mathrm{w}$ niej, że bezpieczeństwo społeczne odnosi się do utrzymywania, $w$ zadowalajacych warunkach rozwoju, tradycyjnych wzorców języka, kultury $i$ tożsamości religijnej, narodowej oraz zwyczajów ${ }^{2}$. Stąd istota bezpieczeństwa we współczesnych stosunkach międzynarodowych wydaje się nieść dziś

${ }^{1}$ Fragmenty niniejszej publikacji zostały wykorzystane w monografii autorki: M. Łakota-Micker, Czarnogóra. Studia nad bezpieczeństwem, Wrocław 2013.

${ }^{2}$ B. Buzan, People, States and Fear: An Agenda for International Security Studies in the Post-Cold War Era, London 1991, s. 18-19. 
nowe treści. Obok tradycyjnych komponentów o charakterze militarnym, pojawiają się także te, odnoszace się do zjawisk sfery ekonomicznej, społecznej czy kulturowej ${ }^{3}$. Wielokrotnie to właśnie one stanowią główne źródło zagrożenia dla bezpieczeństwa państwa. Głęboko zakorzenione w historii i kulturze narodów, potrafią uwidaczniać się w kryzysowych dla państwa momentach, kiedy to szczególnie przybierają na sile i znaczeniu, prowadząc do konfliktu.

Od zakończenia II wojny światowej konflikty wewnętrzne i wojny domowe wybuchały zdecydowanie częściej niż konflikty międzynarodowe lub międzypaństwowe. Badania, mające znaleźć odpowiedź na pytanie o przyczynowość konfliktów, skupiają się przede wszystkim na kwestiach i czynnikach etnicznych, środowisku, polityce i gospodarce. Nie są one jednak w stanie jasno określić rzeczywistych przesłanek, z powodu których dochodzi do konfliktów. Wśród różnych teorii można znaleźć twierdzenie wskazujące na fakt, że istnienie czynników etnicznych i religijnych jest w stanie redukować ryzyko wybuchu konfliktu. Dopóki podzielone grupy prowadzą wspólną koegzystencję, asymilują się, różnorodność nie stanowi problemu. Kiedy jednak pojawiaja się odrębne wizje, idee - system zawodzi. Istniejący podział etniczny może obrócić się w zaostrzony konflikt i zwiększyć

${ }^{3}$ Pojęcie wielokulturowości rozumiane jest najczęściej na trzy sposoby. Po pierwsze, w płaszczyźnie opisowej wskazuje na wielość kultur, jest więc stwierdzeniem obiektywnego faktu zróżnicowania kulturowego danego społeczeństwa. Po drugie, oznacza również politykę rządowa, zmierzająca do niwelacji napięć społecznych, związanych z faktem wielokulturowości danej populacji. Po trzecie, stanowi nazwę pewnej doktryny, ruchu, a nawet filozofii. W ostatnim przypadku wielokulturowość oznacza działania środowisk mniejszościowych skierowane na emancypację i ich pełniejszy udział w życiu społecznym, politycznym i kulturalnym kraju, Encyklopedia PWN, http://encyklopedia.pwn.pl (dostęp 16 XII 2012). 
prawdopodobieństwo poważnej eskalacji ${ }^{4}$. Tło wydarzeń lat 90. XX w. i działania zbrojne, jakie miały miejsce na terenie byłej Jugosławii, doskonale potwierdzają przyjęte powyżej twierdzenie. Pokazuja, że jednoczesne sprzężenie wielu czynników, nie odnoszących się bezpośrednio wyłącznie do sfery militarnej, a wynikajacych głównie ze złej sytuacji gospodarczej, różnorodności wyznaniowej, językowej i kulturowej, przyczyniło się do wybuchu konfliktu. Dopóki żył sprawujący władzę Josip Broz-Tito, zintegrowane w ramach Jugosławii sześć republik: Słowenia, Chorwacja, Serbia, Bośnia i Hercegowina, Czarnogóra i Macedonia oraz dwa okręgi autonomiczne na terenie republiki serbskiej: Kosowo (z ludnością albańska) i Wojwodina (z ludnością węgierska), były w stanie zapewnić poszczególnym narodom wspólny byt i dążyć do podniesienia ich standardu życia, bez względu na przynależność etniczną czy wyznaniowa. Wraz z pogarszającym się stanem zdrowia przywódcy, system pozbawiony silnej ręki zaczął podupadać. Śmierć Tity w maju 1980 r. stała się momentem, od którego do głosu zaczęli dochodzić przedstawiciele poszczególnych podmiotów federacji. Nastapiło nasilenie tłamszonych od lat nacjonalizmów. Zapaść finansowa i zła sytuacja gospodarcza w Jugosławii oraz zmiany, do jakich doszło w Europie, powodowane rozpadem bipolarnego układu sił, tylko dodatkowo wzmogły protesty i rywalizację poszczególnych narodów. Doprowadziło to ostatecznie do poważnych wstrzasów na Bałkanach. Ich epicentrum stała się Jugosławia ${ }^{5}$. Na destrukcję Socjalistycznej Federacyjnej Republiki Jugosławii (SFRJ) wpłynęły m.in. istniejacce pomiędzy narodami bałkańskimi konflikty, wynikające ze wzajemnych historycznych roszczeń

${ }^{4}$ A. Polak, P. Paździorek, Wojna, konflikt, kryzys, Warszawa 2011, s. 88.

${ }^{5}$ Ibidem, s. 72. 
terytorialnych, czy ingerencji mocarstw europejskich (Wielkiej Brytanii, Francji, Rosji, monarchii habsburskiej) w wewnętrzne sprawy regionu. Niezaprzeczalnym powodem starć stały się animozje zakorzenione wśród przedstawicieli poszczególnych narodów Jugosławii. Półwysep Bałkański to obszar, gdzie religia i etniczość Słowian południowych połączyły się tak ściśle, jak nigdzie indziej we współczesnej Europie. Każda z grup narodowościowych definiowała bowiem swoją własną tożsamość, ukazując odrębne symbole, obrazy i mity, jakich dostarczała im katolicka, prawosławna, bądź muzułmańska kultura religijna. Czynnik kulturalny, wielokrotnie wykorzystywany dla realizacji celów politycznych, uwzględniający mitologię narodowa, zdawał się mieć niebywały wpływ na destabilizację na Bałkanach. Kultura, która zamiast stanowić nośnik wzajemnego porozumienia i współpracy, została bezpośrednio zaadaptowana w konflikty regionalne i posłużyła eskalacji nastrojów i postaw nacjonalistycznych ${ }^{7}$. Wielokulturowość i wielowyznaniowość narodów Jugosławii ${ }^{8}$ wpływała na zróżnicowanie kultur, tradycji i poglądów. Narodów, które w obliczu dążeń separatystycznych Słoweńców, wystąień równie przywiązanych do Zachodu i dowodzących swych korzeni chrześcijańskich Chorwatów, chcących niezależności od Serbów; prawosławnych Serbów, nawiązujących do źródeł historii Jugosławii i głoszących wielkoserbskie idee; Albańczyków, występujących m.in. $\mathrm{w}$ Kosowie, walczaccych o nadanie temu ostatniemu statusu

${ }^{6}$ F. Gołembski, Geokulturowe uwarunkowania stosunków politycznych na Bałkanach, [w:] Bałkany. Etnokulturowe podtoże konfliktów, red. nauk. W. Konarski, A. Koseski, Pułtusk 2006, s. 76.

${ }^{7}$ Ibidem, s. 90.

${ }^{8}$ Obywatele Serbii i Czarnogóry to głównie wyznawcy prawosławia, Bośni i Hercegowiny, Albanii - to w dużej mierze muzułmanie, Chorwaci i Słoweńcy - to katolicy. 
republiki; czy rosnących aspiracji bośniackich Muzułmanów, o których przyjęło się mówić, że stanowią wspólnotę nie tylko religijna, ale i narodowa - nie dały się zasymilować. Deprecjonowane od wielu lat problemy uwydatniły się, doprowadzając do eskalacji konfliktu na niewyobrażalna skalę. Federację opuszczały kolejno: Słowenia i Chorwacja, następnie Macedonia, Bośnia i Hercegowina, Czarnogóra, aż wreszcie w 2008 r. Kosowo. Najkorzystniejszym rozwiazaniem, które miało doprowadzić do zapewnienia stabilności i bezpieczeństwa na Bałkanach, wydawało się być stworzenie małych państw narodowych. Państw zachowujących swoją własną tożsamość, nieuwikłanych w konflikty pomiędzy walczącymi o swoje prawa narodowościami i mniejszościami narodowymi, jak i grupami etnicznymi ${ }^{9}$. Utworzenie państw o charakterze homogenicznym okazało się jednak niemożliwe. Jednostki zmuszone zostały do poszukiwania nowych rozwiązań, tożsamości i sposobów samoidentyfika$\mathrm{cji}^{10}$. O ile dążenia Słowenii, Chorwacji, Macedonii, Bośni i Hercegowiny do uzyskania pełnej suwerenności wyrażane były jasno już z początkiem lat 90 . XX w., o tyle powiązania instytucjonalne, wojskowe, ekonomiczne Serbii i Czarnogóry nie pozwoliły tej ostatniej w podobny sposób manifestować chęci uzyskania niezależności państwowej. Serbia i Czarnogóra, jako kontynuatorki SFRJ, utworzyły 27 kwietnia 1992 r. Federalną Republikę Jugosławii, która 4 lutego 2003 r. przekształcona została w Serbię i Czarnogóręe ${ }^{11}$.

${ }^{9}$ I. Rycerska, Rozpad Jugosławii. Przyczyny i przebieg, Kielce 2003, s. 184 .

${ }^{10}$ W.M. Stankiewicz, Konflikt jako zjawisko integrujace $i$ dezintegrujace oblicze wspótczesnego świata, Olsztyn 2008, s. 79.

${ }^{11}$ Więcej zob.: W. Walkiewicz, Czarnogórców droga do niepodlegtości, [w:] Batkany Zachodnie między przeszłościa a przyszłościa, pod red. P. Chmielewskiego i S.L. Szczesio, Łódź 2013, s. 443-452; W. Szczepański, 
Dzięki porozumieniu, które zostało zawarte pomiędzy prezydentami Serbii i Czarnogóry, przez trzy lata funkcjonował dość nietypowy podmiot, posiadający charakter konfederacji z pewnymi cechami federacji ${ }^{12}$. W 2006 r., na drodze pokojowej, obywatele - za pośrednictwem referendum - przesadzili o odłączeniu Czarnogóry od Serbii. Opuszczając federację z Serbia, Czarnogóra stała się niezależnym podmiotem prawa międzynarodowego. Obawy elit rządzących w Czarnogórze, które jeszcze w latach 90 . XX w. zakładały, iż jej nikły potencjał ekonomiczny nie pozwoli funkcjonować jako samodzielne państwo, okazały się nieuzasadnione. Udało się sprostać problemom natury wojskowej i ekonomicznej. Źródłem, mogącym zagrażać bezpieczeństwu państwa, wydawać się mogła natomiast kwestia wielokulturowości niepodległej Czarnogóry. Wielokulturowość, określana jako współistnienie odmiennych wartości i tradycji, skumulowanych w ramach jednego organizmu państwowego, poddana została demokratyzacji ${ }^{13}$. W przyjętej w 2007 r. Konstytucji Czarnogóry, nowy kraj określony został jako wielonarodowy, wielokulturowy i umożliwiajacy używanie, poza językiem czarnogórskim, także innych języków, którymi posługują się mniejszości narodowe, zamieszkujące jego terytorium. W ten sposób w Czarnogórze doszło do upublicznienia i instytucjonalizacji „zamrożonych“ dotychczas różnorodnych wartości, interesów i tożsamości kulturowych. Otwartość i demokratyczne podejście władz państwa do problemu w perspektywie siedmioletniej znalazły słuszne uzasadnienie. Okazały się mieć zasadnicze znaczenie i pozwoliły uniknąć kolejnych

Pożegnanie z Jugostawia: Wspólnota Państwowa Serbia $i$ Czarnogóra (2003-2006), [w:] ibidem, s. 461-475.

${ }^{12}$ Szerzej zob.: J. Wojnicki, System konstytucyjny Czarnogóry, Warszawa 2012; idem, System konstytucyjny Serbii i Czarnogóry, Warszawa 2005.

${ }^{13}$ W.M. Stankiewicz, op. cit., s. 79. 
napięć w Czarnogórze, państwie zamieszkanym przez ludność o różnym pochodzeniu etnicznym.

$$
* * *
$$

Heterogeniczność narodowościowa współczesnych państw, w tym Czarnogóry, stanowi, z punktu widzenia ich bezpieczeństwa, jedno z kluczowych wyzwań. Jest swoistym testem na stabilność demokracji, umiejętność rozwiązywania konfliktów o podłożu narodowościowym oraz funkcjonowanie skutecznych rozwiązań formalnoprawnych. W przypadku Czarnogóry, jako państwa zabiegajacego o akcesję do struktur współpracy państw szeroko rozumianego Zachodu, heterogeniczność należy postrzegać w dwóch wymiarach. Z jednej strony, jako swoiste wyzwanie dla Czarnogóry jako młodego państwa, z drugiej natomiast - jako potencjalny problem dla struktur, do których członkostwa ona pretenduje. Przed Czarnogóra, zmierzająca do NATO i Unii Europejskiej (UE), stoi istotne zadanie udowodnienia stabilności i skuteczności we wdrażaniu rozwiązań obecnie obowiązujących na tym obszarze, jak i takiej ich modyfikacji, aby możliwe było bezkonfliktowe współistnienie w jednej przestrzeni państwowej wielu różnych grup narodowościowych i wyznaniowych.

$$
* * *
$$

Zgodnie z przeprowadzonym w $1991 \mathrm{r}$. spisem ludności - jeszcze za czasów przynależności Czarnogóry do SFRJ - terytorium Czarnogóry zamieszkiwało 615035 mieszkańców ${ }^{14}$. Narodowość czarnogórską deklarowało 380467 osób, czyli

${ }^{14}$ Stanouništvo prema nacionalnoj ili etničkoj pripadnosti prema popisu 1981, 1991 i 2003. godine, MONSTAT Crne Gore, Zavod za statistiku Crne Gore; P. Eberhardt, Przemiany demograficzno-etniczne na obszarze Jugostawii w XX wieku, Lublin 2005, s. 123. 
61,86\% ogółu ludności. Do największych mniejszości narodowych należeli: Muzułmanie - 89614 (14,57\%) obywateli, Serbowie - 57453 (9,34\%), Albańczycy - 40415 (6,57\%) oraz osoby określające się jako Jugosłowianie - 26159 (4,25\%). Jako potencjalne zagrożenie dla stabilności republiki czarnogórskiej widziano wówczas dość charakterystyczne skupianie się (grupowanie) wyżej wymienionych mniejszości w poszczególnych obszarach państwa. Jak pisze Piotr Eberhardt, Muzułmanie w 1991 r. osiedlali się w północno-wschodniej części Czarnogóry, tj. na obszarze graniczącym z Serbią. W gminie Rožaj, liczącej 22,9 tys. mieszkańców, ludność muzułmańska stanowiła $87,6 \%$ populacji (20,4 tys.), w gminie Plav - 58,1\% (11,2 tys.), w Bjelo Polje - 41,7\% (23 tys.), a w Berane $-25,8 \%$ $(11,8 \text { tys. })^{15}$. Przy granicy z Albania, w gminie Ulcinj, zgodnie z danymi ze spisu ludności, dominowali Albańczycy, stanowiący 17,6 tys. mieszkańców (tj. 71,1\% ogółu ludności). Liczna mniejszość albańska zamieszkiwała gminy Plav i Bar. Ludność serbska rozproszona była na terytorium całej Czarnogóry. Najwięcej Serbów w 1991 r. mieszkało w gminie Herceg Novi $(30,9 \%)$ i Pljevlja $(24,4 \%)^{16}$.

Kolejny spis ludności przeprowadzony został na terytorium Czarnogóry w 2003 r., tj. kiedy współtworzyła ona z Serbia związek państw, wchodzących w skład federacji. Już we wstępie opracowania, które powstało w wyniku badań demoskopowych, wyraźnie zwraca się uwagę na różnice, jakie zaszły $\mathrm{w}$ rozmieszczeniu ludności na terytorium Czarnogóry ${ }^{17}$.

Nie bez znaczenia na migracje $\mathrm{w}$ obrębie państw byłej Jugosławii miał jej rozpad. Zgodnie ze spisem, obszar

${ }^{15}$ P. Eberhardt, op. cit., s. 123.

${ }^{16}$ Ibidem.

${ }^{17}$ Popis stanovništva, domačinstva $i$ stanova u 2003, Zavod za statistiku Crne Gore, Podgorica 2005. 
Czarnogóry w 2003 r. zamieszkiwało 620145 osób, tj. o 5110 więcej niż wynika ze spisu z $1991 \mathrm{r} .{ }^{18} \mathrm{~W}$ porównaniu do wcześniejszych wyników, liczba osób podających się jako Czarnogórcy uległa zmniejszeniu o 112798 osób (w 2003 r. wynosiła 267 669, tj. 43,16\%), czyli o 18,73\%. Najbardziej zauważalna zmiana okazało się zmniejszenie się liczby Muzułmanów, których w 2003 r. było 24625 osób (3,97\%), o 64989 osób (tj. o 10,6\%) mniej niż przed niecałymi 10 laty. Tuż po Czarnogórcach, na drugim miejscu pod względem liczebności, znaleźli się Serbowie - 198414 osób. Ich liczba wzrosła o 140961 osób, tj. o 22,65\%. Na terenie Czarnogóry pojawili się tzw. Boszniacy (48 184 osób, tj. 7,77\%), którzy nie byli wcześniej uwzględniani tu $\mathrm{w}$ spisach ludności. Liczba „Jugosłowian” zmalała do 1860 osób, tj. do 0,30\% (z 4,25\%). Charakterystyczne było ponadto pojawienie się tzw. osób nieokreślonych, co odnotowano w stosunku do 26906 osób, tj. 4,34\% (dla porównania - w 1991 r. było ich zaledwie 1944, tj. 0,32\%). Jak podkreśla się, w spisie z 2003 r., zgodnie z zaleceniami międzynarodowymi, brano pod uwagę zarówno obywateli zamieszkujących Czarnogórę na stałe, jak i mieszkańców republiki, przebywających poza jej granicami (głównie ze względów zarobkowych) nie dłużej niż rok, jak i obcych obywateli, którzy pracowali wówczas w republice czarnogórskiej lub zamieszkiwali ją jako członkowie rodzin w okresie dłuższym niż rok.

Jak wynika z powyższych danych, na terytorium niewielkiego państwa doszło do znamiennych zmian o charakterze narodowościowym. Za istotny można przyjać tu fakt, że w 1999 r. - za przyzwoleniem prezydenta Milo Đukanovicia - w Czarnogórze schronienie znalazło około 7 tys. uchodźców z Kosowa, głównie pochodzenia serbskiego

${ }^{18}$ Stanouništvo prema nacionalnoj ili... 
i romskiego ${ }^{19}$. Badacze dopatrują się $\mathrm{w}$ tak dużej liczbie osób, deklarujących się w 2003 r. jako Serbowie, również możliwości zmiany opcji narodowościowej przez część Czarnogórców. Pewnym wytłumaczeniem tego mogą być warunki polityczne, jakie istniały w trakcie spisu. Społeczeństwo czarnogórskie postawione było przed trudnym sprawdzianem, jakim stało się określenie przyszłego statusu politycznego ich kraju. Wielu mieszkańców, w tym czołowi działacze, było zwolennikami secesji i stworzenia niepodległej Czarnogóry. Liczni, rdzenni Czarnogórcy, odczuwający więź z Serbami, nie byli jednak za takim rozwiązaniem. Obawiali się konfrontacji z Serbia, a trudna sytuacja gospodarcza tym bardziej powstrzymywała ich przed jakimikolwiek krokami, które jeszcze bardziej mogły wpłynać na jej pogorszenie. Obawiano się także ekspansji albańsko-muzułmańskiej ${ }^{20}$.

Konstytucja Czarnogóry z 2007 r. określa ja już w preambule jako państwo obywatelskie, które tworza narody $i$ mniejszości narodowe: Czarnogórcy, Serbowie, Boszniacy, Albańczycy, Muzutmanie, Chorwaci i inni, przywiazani do demokratycznej i obywatelskiej Czarnogóry. Zgodnie z Ustawa zasadnicza, zdefiniowane zostało również obywatelstwo, stanowiące, w momencie ustalania nowych ram konstytucyjnych, podłoże potencjalnych konfliktów i napięć między Czarnogórą a Serbią, a w szczególności w kwestii nadania czarnogórskim Serbom podwójnego obywatelstwa. Zgodnie z Konstytucja, wszyscy obywatele Czarnogóry, którzy na dzień 3 czerwca

${ }^{19} \mathrm{~W}$ trakcie kryzysu kosowskiego Czarnogóra była państwem, które przyjęło na swoje terytorium uchodźców ze wszystkich krajów byłej Jugosławii, a trudna do określenia liczba osób opuściła państwo. W 1999 r. uchodźcy i przesiedleńcy stanowili ponad $20 \%$ populacji Czarnogóry, Upitnik, Vlada Crne Gore, Ministarstvo za evropsku integraciju, Podgorica, 24 XI 2009, s. 6.

${ }^{20} \mathrm{~W}$ oparciu o: P. Eberhardt, op. cit., s. 123. 
2006 r., obok macierzystego obywatelstwa posiadali także obywatelstwo innego panstwa, maja prawo do zachowania obywatelstwa czarnogórskiego. Natomiast obywatele republiki, którzy od tego samego dnia pozyskali również drugie obywatelstwo, maja prawo do zachowania czarnogórskich paszportów do czasu podpisania bilateralnego porozumienia $z$ krajem, którego obywatelstwo uzyskali ${ }^{21}$.

Zgodnie z danymi ostatniego spisu powszechnego, przeprowadzonego w Czarnogórze w 2011 r., państwo zamieszkuje 620029 mieszkańców ${ }^{22}$. Największa ich liczba skupiona jest w stolicy - Podgoricy - 185937 (30\%), następnie w miejscowościach: Nikšić i Bjelo Polje, gdzie koncentruje się ponad 50\% mieszkańców Czarnogóry. Struktura etniczna nowego państwa przedstawia się następująco: największą zbiorowość stanowią Czarnogórcy (278 865 osób), następnie Serbowie (178 110), Boszniacy (53 605) i Albańczycy (30 439). Co ciekawe, w ostatnich badaniach demoskopowych na pytanie o pochodzenie etniczne 4,87\% respondentów odmówiło odpowiedzi, nie chcąc deklarować swej przynależności do konkretnej grupy. Podobnie było, gdy pytano o język ojczysty (3,99\%), czy religię $(2,61 \%)^{23}$.

Jak wynika z powyższego zestawienia, Serbowie stanowią drugą co do wielkości grupę narodowościową w Czarnogórze. W obliczu najnowszej historii i związków Czarnogóry z Serbią

${ }^{21}$ Więcej na temat zob. Ł. Kobeszko, Czarnogóra, przyjęto nowa konstytucje, http://www.psz.pl/91-europa/czarnogora-przyjeto-nowa-konstytucje (dostęp 20 VIII 2011).

${ }^{22}$ Spis, dokonany na potrzeby agencji MONSTAT w 2011 r., pokazuje, że pod względem narodowościowym Czarnogórę zamieszkuje 45\% Czarnogórców, 29\% Serbów, 9\% Boszniaków, 5\% Albańczyków, 3\% Muzułmanów, Popis 2011, Crna Gora u brojkama, Zavod za statistiku Crne Gore, Podgorica 2012.

${ }^{23}$ Ibidem. 
oraz stosunku Serbii do NATO i UE może to w przyszłości generować pewne konflikty.

Współczesna struktura etniczna Czarnogóry stanowi interesujące studium przypadku. Religijnie i kulturowo kraj ten bliski jest Serbii. Wspólna historia obu narodów i szczególne więzy, jakie łączyły te państwa, nie pozostały bez znaczenia również dla dzisiejszych kontaktów. Stosunki serbsko-czarnogórskie zostały wystawione na próbę po konflikcie w Kosowie. Rysujące się pod koniec lat 90. ubiegłego stulecia różnice w interesach i odrębne idee, co do przyszłego kształtu Serbii i Czarnogóry, poróżniły stojące u władzy elity. Tendencje separatystyczne i zarzuty wobec Belgradu, m.in. o narzucanie politycznej hegemonii i kulturalnej dominacji były coraz bardziej akcentowane. Właśnie wówczas grupa czarnogórskich intelektualistów, posiadających znaczące wpływy wśród ekipy sprawującej władzę, rozpoczęła kampanię o charakterze niepodległościowym, podkreślając w swych wystapieniach odrębność narodu czarnogórskiego. Za sprawą ich działalności doszło do wyraźnej polaryzacji stanowisk wśród społeczeństwa czarnogórskiego. Poza osobami, które bagatelizowały różnice kulturowe pomiędzy Serbami a Czarnogórcami i wskazywały na niebezpieczeństwo ze strony Albańczyków, inni dowodzili konieczności odtworzenia w pełni suwerennego państwa czarnogórskiego. Pojawiły się głosy o potrzebie wyodrębnienia narodu czarnogórskiego. Na owe spory nałożyła się kwestia odrębności językowej, która zyskała wymiar polityczny. Stała się obiektem polemiki, na stałe różniącym językoznawców serbskich i czarnogórskich, ale i jednocześnie pobudzającym do działania nacjonalistów czarnogórskich. Wysuwane przez zwolenników języka czarnogórskiego liczne argumenty, negowane były jednak przez specjalistów serbskich ${ }^{24}$.

${ }^{24}$ P. Eberhardt, op. cit., s. 122. 
Rozpad federacji w 2006 r. nie zakończył polemiki, dotyczącej istnienia języka czarnogórskiego. Trwa ona nadal. Stanowi przedmiot debat pomiędzy przedstawicielami świata nauki - filologami czarnogórskimi i serbskimi ${ }^{25}$. Jak dowodzi profesor literatury czarnogórskiej na Wydziale Filologicznym w Nikšiciu - Vojislav Nikčevićc ${ }^{26}$, prowadzone przez ponad 30 lat badania wskazuja na odrębność języka Czarnogórców od języka Serbów. Swoisty charakter języka wiąże się nie tylko z istnieniem narodu czarnogórskiego. Język czarnogórski ma swoja odrębna, szczególna geneze, swoje odrębne pochodzenie, własny naród, własna bardzo rozwinięta literature, wybitne dzieta literackie [...]. Język czarnogórski ma wiele typowych cech, które potwierdzaja $w$ petni jego socjolingwistyczna tożsamość w odróżnieniu od języka serbskiego, który jest ponadnarodowy: do dziś nie posiada żadnego systemowego elementu, którym można by potwierdzić, iż jest specyficznie serbski - stwierdził Nikčević ${ }^{27}$.

Czarnogórskim, jako językiem urzędowym, posługują się nie tylko Czarnogórcy, ale i serbscy mieszkańcy Czarnogóry, Bośni i Hercegowiny, Chorwacji. Zgodnie z Konstytucja, dopuszczalne jest w celach urzędowych posługiwanie się językami: serbskim, bośniackim, albańskim oraz chorwackim ${ }^{28}$. Kiedy w 2003 r. Serbia i Czarnogóra utworzyły luźną federację państw, ze szkół czarnogórskich usunięto przedmiot o nazwie „,język serbski” i zastapiono go językiem serbskim, czarnogórskim, chorwackim lub bośniackim. Trzy lata później, kiedy Czarnogóra uzyskała niepodległość, postanowiono zmienić

${ }^{25}$ Więcej nt. języka czarnogórskiego zob. „Lingua Montenegrina. Časopis za jezikoslovna, knijiževna i kulturna pitanja" [Cetinje] 2009, god. 2, br. 3.

${ }^{26}$ Szerzej zob. Czy istnieje język czarnogórski?, http://postslavia.filg. uj.edu.pl/html/zasoby/artykuly/jezyk/czarnogorski.pdf (dostęp 25 XI 2012).

${ }^{27}$ Ibidem.

${ }^{28}$ Konstytucja Czarnogóry; zob. też Ł. Kobeszko, op. cit. 
standardy językowe. Wprowadzono do alfabetu czarnogórskiego dodatkowe litery (względem alfabetu serbskiego). W dzisiejszej Czarnogórze dominuje alfabet łaciński. Od 2012 r. czarnogórskie abecadło, zgodnie z wcześniejszymi założeniami zyskało dwie nowe litery - ź (w cyrylicy zapisywane jako 3 z kreska) oraz ś (w cyrylicy ć), w ten sposób powiększając ich liczbę z 30 do 32 . W szkołach zaczęto realizować lekcje języka czarnogórskiego.

Dla Serbów, których dzieci mówią językiem serbskim i uczęszczają do szkół czarnogórskich, powyższe zmiany są nie do przyjęcia. Podkreślają oni, że do czasu, gdy serbski nie stanie się językiem równorzędnym, Serbowie będą bojkotować lekcje czarnogórskiego w szkołach. W odpowiedzi rząd Czarnogóry obiecuje dodatkowe lekcje języka serbskiego. Mimo to, głównym językiem wykładanym w szkołach pozostaje czarnogórski. Tym samym oznacza to, że serbski znajduje się na równi z albańskim, bośniackim i chorwackim, czyli językami mniejszości narodowych w Czarnogórze ${ }^{29}$. Mając na uwadze liczbę Serbów, zamieszkujących terytorium Czarnogóry, należy stwierdzić, że taka struktura programów nauczania języka może być odbierana jako przejaw dyskryminacji narodowej.

Podobnie, jak w przypadku jezzyka, tak i w wymiarze religijnym, Konstytucja Czarnogóry z 2007 r. określa stosunki pomiędzy państwem a Cerkwia prawosławna. Obowiązuje rozdzielność Państwa od Kościoła. Pod względem wyznania, w dzisiejszej Czarnogórze dominuje prawosławie. Deklaruje je $72 \%$ obywateli, $19 \%$ stanowia wyznawcy islamu, $3 \%$ katolicy, $1 \%$ ateiści, pozostali $5 \%{ }^{30}$. Większość

${ }^{29}$ Język serbski $w$ Czarnogórze, http://serbia.blog.pl/2011/08/16/jezykserbski-w-czarnogorze/ (dostęp 20 VIII 2011).

${ }^{30}$ Ibidem. 
czarnogórskich prawosławnych przynależy do metropolii czarnogórsko-primorskiej Serbskiej Cerkwi Prawosławnej ${ }^{31}$.

${ }^{31}$ Początek dominacji prawosławia w Serbii sięga rodu Nemanjiciów. W 1217 r. Stefan I, syn Stefana Nemanji, przyjął insygnia królewskie z rąk legata papieża Innocentego III. Jednak jego brat Sawa doprowadził do zerwania związku z papieżem i Rzymem. W 1219 r. Sawa otrzymał od Cesarstwa Nicejskiego (grecki spadkobierca Bizancjum) sakrę arcybiskupią w Žicy oraz 10 diecezji, co dało początek autokefalicznej Serbskiej Cerkwi Prawosławnej. W Zecie siedzibą diecezji był monaster św. Michała na Prevlace w Boce Kotorskiej. Za panowania cara Dušana diecezja zecka została podniesiona do rangi metropolii. Nie podobało się to jednak Wenecjanom, którzy na zdobytych obszarach utrudniali funkcjonowanie Kościoła. Biskupi zeccy zmuszani byli kilkakrotnie zmieniać swoją siedzibę, przenosząc ją z Budvy do Baru, Vranjina na Jeziorze Szkoderskim, do monasteru św. Mikołaja na wzgórzu Obod i Rijeki Crnojevića. Od 1484 r. siedziba Cerkwi stał się monaster w Cetinju, do dnia dzisiejszego uznawanym za główne centrum Kościoła Prawosławnego w Czarnogórze. Po zlikwidowaniu przez Turków patriarchatu serbskiego w Peci, władzę nad Serbską Cerkwią Prawosławna przejęło arcybiskupstwo ochrydzkie. Greccy biskupi szerzyli wśród Słowian liturgię grecka. Przywrócony w 1557 r. za sprawą bośniackiego Serba - wezyra Mehmeda Paszy - patriarchat w Peci został w 1766 r. ponownie zlikwidowany. Czarnogórscy duchowni, nie uznając podległości Grekom, zwrócili się o opiekę do serbskiego patriarchatu w Sremskich Karlovcach (wówczas Austria, obecnie Serbia), a później do Cerkwi rosyjskiej. W ten sposób powstały dwie hierarchie: serbska i czarnogórska. Od końca $\mathrm{XV}$ w. autorytet wśród czarnogórskich plemion zdobywał stopniowo metropolita Kościoła prawosławnego w osobie biskupa cetyńskiego. Kolejni biskupi zyskiwali coraz większą władzę świecka, aż do chwili uzyskania tytułu władyki. W 1697 r. tron władyków objęła dynastia Petroviciów, której pierwszym przedstawicielem został Danilo, panujacy w latach 1697-1735. Dzięki poparciu bliskich rządowi w Podgoricy kręgów powołana została do życia niekanoniczna Cerkiew Czarnogórska. Autokefaliczna Czarnogórska Cerkiew Prawosławna funkcjonowała do 1920 r. W 1993 r. została założona ponownie, jednak jej rejestracji dokonano dopiero w 2000 r., co nie obyło się bez sporów i debat wokół tej sprawy. Zdaniem czarnogórskich Serbów, jak i Serbskiej Cerkwi Prawosławnej, Czarnogórska Cerkiew to nielegalnie działająca sekta, która powstała z powodów politycznych, a nie religijnych, 
Zgodnie z Konstytucja, wspólnoty religijne w Czarnogórze sa równoprawne i posiadaja swobodę $\mathrm{w}$ realizowaniu swoich praw, co wynika z oddzielenia kwestii wyznaniowych od państwa $^{32}$. Wobec powyższego wydawać by się mogło, iż wyznanie stanowić powinno potencjalny czynnik neutralizujacy konflikty na tle narodowościowym, rodzące się pomiędzy Serbami a Czarnogórcami. Taka konkluzja nie wydaje się jednak zasadna. Jak podkreśla biskup Hilarion ${ }^{33}$ - patriarcha Wiednia i Austrii oraz przewodniczacy Wydziału Zewnętrznych Stosunków Kościelnych Patriarchatu Moskiewskiego, Czarnogóra jest wielowyznaniowym państwem $z$ prawostawna większościa, jednak jedynym prawowitym Kościotem prawostawnym jest Serbski Kościót Prawostawny, a poszanowanie prawa kanonicznego wyklucza, by na jednym terytorium istniaty dwa prawostawne Kościoty. I dodaje: niemożliwym jest, aby tworzyć nowy Kościót wtedy, kiedy powstaje nowe państwo, gdyż wówczas zamiast 15 Kościotów prawostawnych bytoby ich $150^{34}$. W odpowiedzi Cerkiew Czarnogórska stwierdza, że gdy Kościół Serbski był

i która podważa autorytet oraz osłabia wpływy Cerkwi Serbskiej na obszarze Czarnogóry, Czarnogóra. Religia, Bezdroża, 16 VI 2008, http://turystyka.wp.pl/kat,1036545,title,Religia,wid,15564929, wiadomosc.html?ticaid=115da9\&_ticrsn=3 (dostęp 20 VIII 2011).

32 七. Kobeszko, op. cit.

${ }^{33}$ Podobnego zdania są również pozostali biskupi, m.in. cieszący się dużym autorytetem metropolita Serbskiej Cerkwi w Czarnogórze, biskup Amfilohije, według którego niedopuszczalne jest zredukowanie Cerkwi do miana jednej ze wspólnot wyznaniowych. Jego zdaniem, język serbski nie został w konstytucji uznany za równoprawny z czarnogórskim, co zasługuje na potępienie, gdyż język, określany mianem czarnogórskiego, jest sztucznym tworem politycznym, a cała spuścizna kulturalna Czarnogóry powstała w języku serbskim, ibidem.

${ }^{34} \mathrm{D}$. Walencik, Rosyjskie prawostawie nie uzna „czarnogórskiego” Kościoła, http://www.ekumenizm.pl/koscioly/wschodnie/rosyjskie-prawoslawienie-uzna-czarnogorskiego-kosciola/ (dostęp 1 XII 2013). 
kontrolowany przez Turków, to Kościół Czarnogórski był Kościołem niezależnym i uznawanym przez Święty Synod Rosyjskiego Kościoła Prawosławnego. Tym samym za słuszne uważa zwrot 650 przejętych przez Serbów monasterów i cerkwi na terytorium Czarnogóry.

Jak można zauważyć, w dwu ostatnich dziesięcioleciach XX w. Serbska Cerkiew Prawosławna (SPC) ewoluowała. Kościół, funkcjonujący wcześniej na marginesie życia społecznego, nieprzygotowany do zachodzących zmian polityczno-społecznych, został zmuszony do zajęcia stanowiska wobec problemu biologicznego zagrożenia egzystencji narodu. Przypisana Cerkwi jeszcze na poczatku lat 90 . XX w. przez duchownych potrójna rola depozytariusza i obrońcy autentycznej tożsamości narodowej ${ }^{35}$, gwaranta zachowania terytorialnej jedności ziem serbskich (tj. ziem zamieszkałych przez Serbów) oraz fundamentu, na którym budowana będzie przyszłość Serbów - nie uległa istotniejszym zmianom. W ciagu ostatnich lat Cerkiew funkcjonowała w społeczeństwie jako instytucja nad wyraz zaangażowana w sprawy polityczno-społeczne, która, w opinii znawców przedmiotu, odegrała niechlubną rolę w procesie rozpadu państwa jugosłowiańskiego. Od lat 90. ubiegłego stulecia znaczna część hierarchów cerkiewnych koncentrowała się w swych działaniach na wręcz „etnofiletycznie” postrzeganym „problemie narodowym”. Cerkiew, w latach kolejnych, służyła politykom jako istotne narzędzie manipulacji, dzięki któremu zrealizowany zostać miał „projekt Wielkiej

${ }^{35}$ D. Gil, Serbska Cerkiew Prawostawna po „rewolucji październikowej” 2000 roku, s. 3, http://postjugo.filg.uj.edu.pl/cerkiew.pdf (dostęp 1 XII 2013); por. R. Radić, Crkva u politici i politika u Crkvi, [w:] Srpska elita, Beograd 2000 (seria: „Helsinške sveske”), s. 40. 
Serbii”. Wraz z odsunięciem od władzy Slobodana Miloševicia, polityczne zaangażowanie SPC uległo zmniejszeniu ${ }^{36}$. Nie oznacza to jednak, że Serbska Cerkiew Prawosławna nie jest dziś postrzegana, podobnie jak to miało miejsce w latach 90 ., jako doskonały środek przekazu politycznych poglądów i ideologicznej manipulacji państwa serbskiego. Mimo że Cerkiew prawostawna nie jest, jak myśli wielu, ani „narodowa”, ani „a-(nie)narodowa” ani „ponadnarodowa”, jest ona, biorqc pod uwage skład narodowy swych członków, (była i powinna być) wielonarodowa ${ }^{37}$. Zdaniem teologa Radovana Bigovicia, terytorialna zasada, dotycząca organizacji Cerkwi prawosławnej, praktycznie nie odgrywa żadnej roli ${ }^{38}$, to jednak Serbowie, mieszkajacy poza obszarem państwa, zmieniali wiare, a co za tym idzie - tożsamość narodowa, przyczyniajac się $w$ ten sposób do powstania nowych nacji ${ }^{39}$. Utworzone dzięki temu Macedońska i Czarnogórska Cerkiew Prawosławna, mimo sugerowanej równości i ponadnarodowości cerkiewnej, stanowia przykład wpływu antagonizmów narodowych na możliwość sterowania Kościołem.

$$
* * *
$$

Czarnogóra nie uniknęła spięć o charakterze religijnym, zwłaszcza między serbskim a czarnogórskim kościołami prawosławnymi. Konflikt dotyczył przede wszystkim prawa własności do znajdujących się na terenie kraju cerkwi i obiektów kościelnych. Problemy wiązały się też z określeniem w Konstytucji roli Kościoła i tego, który z dwóch uznany zostanie za narodowy. Czarnogórski Kościół prawosławny podkreślał, że jest

\footnotetext{
${ }^{36}$ D. Gil, op. cit.

${ }^{37}$ Ibidem.

${ }^{38}$ Ibidem, s. 11.

${ }^{39}$ Ibidem, s. 12.
} 
jedynym legalnym Kościołem prawosławnym, który może działać na terenie kraju. Akcentował przy tym, że jego majątek został odebrany bezprawnie na początku XX w. Nawoływano, by czarnogórski Kościół przejął wszystkie obiekty kościelne, kaplice i monastyry. Aby chronić mienie serbskie, duchowni Kościoła serbskiego zgłosili się o pomoc do władz Czarnogóry. Ich obawy starał się rozwiać sam prezydent, gdy 10 kwietnia 2007 r. mówił, że zadba o to, aby nie zostały Serbom odebrane święte obiekty. Słowa Filipa Vujanovicia ugodziły jednak przedstawicieli Kościoła czarnogórskiego. Ponadto 8 lipca czarnogórska służba graniczna nie zezwoliła na wyjazd, na terytorium państwa serbskiego, biskupa Filareta Miloševa. Owo zdarzenie starano się tłumaczyć tym, że nazwisko hierarchy widniało na liście Międzynarodowego Trybunału Karnego dla byłej Jugosławii, wśród osób oskarżonych o zbrodnie wojenne. Spektakularne zachowanie biskupa, który przy granicy rozbił obóz i rozpoczął głodówkę ${ }^{40}$, wywołało burzę między dostojnikami Serbii i Czarnogóry. Kiedy 10 sierpnia 2007 r. wysadzono budowany na terenie Czarnogóry serbski kościół, oburzenie Serbów sięgnęło szczytu. Kłótnia między obu kościołami miała wymiar religijny, lecz warto zwrócić uwagę, że dla Podgoricy, która uzyskała niepodległość w 2006 r., istnienie czarnogórskiego Kościoła prawosławnego to też element narodowej tożsamości. Czarnogórscy Serbowie widzieli w jego obecności cios wymierzony w ich narodową kulturę i tradycję. Na skutek sporu, kontakty między Serbią a Czarnogórą uległy pogorszeniu. W celu ich rozwiązania potrzebne było zaangażowanie przedstawicieli Unii Europejskiej ${ }^{41}$. Złe stosunki na linii Belgrad-

${ }^{40}$ Filaret w wyniku strajku głodowego dostał zawału 7 września 2007 r. Dopiero to wpłynęło na decyzję władz czarnogórskich, by umożliwić duchownemu wjazd na terytorium Czarnogóry.

${ }^{41}$ E. Mączyńska, Czarnogóra, „Europa Środkowo-Wschodnia”, R. XVII: 2007 [druk 2008], s. 105-107. 
Podgorica wzmogła dodatkowo, przyjęta 24 września $2007 \mathrm{r}$. przez serbski parlament, uchwała, odnosząca się do podwójnego obywatelstwa. Na jej podstawie o obywatelstwo serbskie mogli ubiegać się wszyscy pełnoletni Serbowie, mieszkający poza granicami kraju ${ }^{42}$.

$$
* * *
$$

Przytaczana tu już wielokrotnie Ustawa zasadnicza Czarnogóry potwierdza wolę dążenia państwa do promocji, umacniania i polepszania ochrony podstawowych praw i wolności obywatela. Zarazem stanowi potwierdzenie polityki państwa w dotrzymywaniu międzynarodowych standardów w powyższym kontekście ${ }^{43}$. Szczególnie istotne dla każdego człowieka sa: ochrona jego praw i wolności, ujęte w art. 6; zakaz podżegania do nienawiści i nietolerancji pod każdym względem (art. 7); zakaz dyskryminacji, niezbędny do korzystania z pozostałych, przysługujących człowiekowi praw i wolności. Czarnogóra, w art. 9 Konstytucji, wyraźnie zapewnia, że ratyfikowane przez państwo i przyjęte międzynarodowe umowy oraz ogólnie uznawane zasady prawa międzynarodowego - stanowią integralną część wewnętrznego porządku prawnego państwa. Co istotne, posiadają one pierwszeństwo przed prawem krajowym i są bezpośrednio stosowane w przypadku, gdy dochodzi do sprzeczności z ustawodawstwem wewnętrznym ${ }^{44}$.

${ }^{42}$ Serbia-Czarnogóra: spór o podwójne obywatelstwo, http://osw.waw. pl/pub/BiuletynOSW/2007/09/070926/best02.htm\#1 (dostęp 11 IX 2012).

${ }^{43}$ Ponad połowa artykułów Konstytucji z 2007 r. (od art. 65 do 158) odnosi się do praw i wolności obywatela.

${ }^{44}$ Mowa tu m.in. o dokumentach ONZ: Międzynarodowym Pakcie Praw Obywatelskich $i$ Politycznych wraz z protokołami fakultatywnymi; Pakcie praw społecznych, gospodarczych i kulturalnych; Konwencji odnoszacej sie do statusu uchodźców; Protokotu międzynarodowej eliminacji wszelkich form dyskryminacji rasowej; Konwencji w sprawie eliminacji wszelkich form 
Aby zapewnić wszystkim obywatelom państwa podstawowe prawa i wolności, bez względu na ich pochodzenie, wyznanie i język, w drugiej części Konstytucji (w art. 79 i 80) przedstawicielom mniejszości narodowych i innych mniejszości gwarantuje się prawa i swobody, z których mogą korzystać indywidualnie lub wspólnie z pozostałymi. Jednocześnie zabrania się asymilacji członków mniejszości, a państwo jest odpowiedzialne za ochronę tych osób przed wszelkimi przejawami celowej asymilacji ${ }^{45}$. Powyższe prawa mniejszości znalazły swoje odzwierciedlenie w Ustawie o prawach mniejszości $i$ ich wolnościach ${ }^{46}$.

dyskryminacji kobiet; Konwencji o prawach dziecka; Konwencji w sprawie zakazu tortur oraz innego okrutnego, nieludzkiego lub poniżajacego postępowania. Czarnogóra zobowiązała się również przyjąć na siebie obowiązki, wynikające z Uniwersalnej deklaracji o prawach człowieka, jako zwyczajowe międzynarodowe zobowiązanie prawne. Spośród instrumentów Rady Europy Czarnogóra przyjęła: Europejska Konwencję o Ochronie Praw Człowieka i Podstawowych Wolności; Europejska Konwencję o zapobieganiu torturom oraz nieludzkiemu i poniżajqcemu traktowaniu lub karaniu; Konwencje ramowa o ochronie mniejszości narodowych; Kartę Języków Regionalnych i Mniejszościowych; Europejskq Kartę Społeczna.

${ }^{45}$ Spośród najistotniejszych praw, gwarantowanych przez Konstytucję mniejszościom zamieszkujacym terytorium Czarnogóry, wymienić można m.in.: prawo do wypowiedzi, ochrony, rozwoju i publicznego okazywania narodowych, etnicznych, kulturowych i religijnych różnic; możliwość używania i odnoszenia się do symboli narodowych i obchodzenia świąt narodowych; nauki i używania własnego języka, alfabetu, zarówno w sprawach urzędowych, jak i prywatnie. Na obszarach, gdzie widoczne jest skupienie się dużej liczby obywateli tej samej mniejszości, lokalne organy administracyjne i sądowe powinny prowadzić postępowania w języku mniejszości; pozwalać na stosowanie podwójnego oznaczania nazw ulic i osiedli; organizować ugrupowania mniejszościowe o charakterze edukacyjnym, kulturalnym i wyznaniowym, udzielać im wsparcia finansowego, dopuszczać do udziału w pracach Skupsztiny i lokalnych władzach.

${ }^{46} \mathrm{~W}$ Czarnogórze za ochronę praw i polepszanie sytuacji mniejszości odpowiedzialne sa przede wszystkim Ministerstwo ds. Ochrony Praw 
Czarnogóra, zgodnie z przedstawionymi powyżej koncepcjami, stara się gwarantować prawa i wolności obywatelom państw Bałkanów Zachodnich (Chorwacji, Bośni i Hercegowiny, Serbii, Kosowa, Albanii i Macedonii), tj. państw, z którymi stanowiła niegdyśs składową część Jugosławii ${ }^{47}$.

Człowieka i Mniejszości Narodowych oraz Komitet Praw Człowieka i Podstawowych Wolności, istniejący na stałe w parlamencie czarnogórskim. Decyzją parlamentu powołano do życia fundusz na rzecz mniejszości, którego zadaniem jest wspieranie działań na rzecz zachowania i rozwoju narodowych, bądź etnicznych różnorodności mniejszości narodowych i innych wspólnot mniejszościowych i ich członków w zakresie identyfikacji ich tożsamości narodowej, etnicznej, kulturowej, językowej i religijnej, por.: Fond za manjine, Sl. list br. 13/08; Strategija Manjinske Politike, Politika Vlade Crne Gore u oblasti poštovanja $i$ zaštite prava manjina, Vlada Crne Gore, Ministarstvo za zaštitu ljudskih i manjinskih prava, Podgorica, jun 2008; Zakon o manjinskim pravima i slobodama, Sl. List RCG br. 31/06, 51/06 i 38/07.

${ }^{47}$ W styczniu 2009 r. rządy Czarnogóry i Chorwacji podpisały Porozumienie o ochronie praw czarnogórskiej mniejszości w Republice Chorwacji, jak i mniejszości chorwackiej zamieszkujacej terytorium Czarnogóry. Porozumienie gwarantuje prawa poszczególnych grup. Prawa czarnogórskiej mniejszości w Chorwacji regulowane są Ustawa o mniejszościach narodowych Republiki Chorwacji z 2002 r., dzięki czemu możliwe było utworzenie Rady czarnogórskiej mniejszości narodowej w Republice Chorwacji. Ma ona czuwać nad udziałem Czarnogórców w życiu publicznym i chronić ich interesy. W preambule czarnogórskiej Konstytucji z 2007 r. wymieniono chorwacki naród, jako jeden z zamieszkujących państwo, a język chorwacki, obok pozostałych języków mniejszości, został wpisany, jako ten, którym Chorwaci mogą posługiwać się, jako urzędowym. Pod koniec $2007 \mathrm{r}$. na terenie Czarnogóry powołano do życia Radę ds. Chorwackiej Mniejszości Narodowej. W Skupsztinie Czarnogóry zagwarantowano miejsce dla przedstawiciela mniejszości chorwackiej. W niektórych miejscowościach, zamieszkiwanych przez Czarnogórców na terytorium Chorwacji, nauczanie na poziomie podstawowym odbywa się w języku czarnogórskim.

Ocenia się, że na terytorium Albanii żyje około 30 tys. przedstawicieli diaspory czarnogórskiej. Funkcjonują tam dwa ugrupowania - Morača, tj. grupa serbsko-czarnogórskiej mniejszości, założona w 1991 r., oraz Alba-Montenegro - z siedzibą w Skodrze, założona 30 czerwca 2001 r. W Czarnogórze Konstytucja 
Ramy prawne i regulacje, odnoszace się do kwestii ochrony i reintegracji uchodźców, jak i wysiedleńców, zamieszkujacych terytorium Czarnogóry od 1992 r., są znaczące. Znalazły się wśród nich m.in.: Strategia długookresowego rozwiazywania problemu uchodźców i wysiedlonych z marca 2005 r.; Ustawa o obywatelstwie Czarnogóry; Ustawa o zatrudnieniu i pracy cudzoziemców; Prawo do opieki zdrowotnej; Ustawa o cudzoziemcach i wiele innych. Mając na uwadze powyższe, wydaje się, że w Czarnogórze problem dyskryminacji o podłożu społecznym i ekonomicznym nie powinien stanowić zagrożenia. Uchodźcom przyznaje się bowiem szereg praw, dzięki którym powinni otrzymać godne warunki do życia w wielonarodowym państwie, za jakie uznaje się w swojej Konstytucji Czarnogóra ${ }^{48}$.

wymienia mniejszość albańska, a język albański uznaje za jeden z urzędowych. Albańska reprezentacja posiada swoich przedstawicieli w Skupsztinie czarnogórskiej, którzy uczestniczą w pracach czterech partii narodowych.

Terytorium Macedonii zamieszkuje 5-10 tys. Czarnogórców. Stworzone zostało tam Ugrupowanie na rzecz Macedońsko-Czarnogórskiej Przyjaźni, jak i Wspólnota Czarnogórców w Macedonii, działające od września 2006 r. Od stycznia 2009 r. działa również kobiece lobby na rzecz czarnogórskiej wspólnoty. Czarnogóra posiada konsulat honorowy w Bitolju.

Jeśli chodzi o czarnogórską mniejszość na terytorium Bośni i Hercegowiny, to stanowi ona jedną z liczniejszych. Pod koniec czerwca 2008 r. utworzono tam Ugrupowanie Czarnogórców i mieszkańców pochodzenia czarnogórskiego. Z jego inicjatywy, 4 maja 2009 r. została podpisana deklaracja o powołaniu przedstawicieli wchodzących w skład Rady koordynującej działalność czarnogórskiej mniejszości narodowej w organach Bośni i Hercegowiny.

Stosunki Czarnogóry z Kosowem w zakresie problematyki mniejszościowej opierają się przede wszystkim na współpracy w zakresie powrotu uchodźców do Kosowa. Jak podaja dane ostatniego spisu powszechnego, przeprowadzonego na terytorium Czarnogóry, przebywa tam 16212 przesiedleńców z Kosowa, a zaledwie 1300 wysiedleńców pochodzenia romskiego opowiedziało się za powrotem. Więcej zob. Upitnik, Vlada Crne Gore, Ministarstvo za evropsku integraciju, Podgorica, 24 XI 2009.

${ }^{48}$ Więcej zob. ibidem. 
Ustosunkowując się do wspomnianych wcześniej starań kraju o członkostwo w organizacjach o charakterze polityczno-ekonomicznym, jak i polityczno-wojskowym, nie sposób nie zauważyć, że stawiany przez nie przed przyszłymi aspirantami niepodważalny wymóg poszanowania praw mniejszości stanowić ma zasadniczy fundament i wyznacznik stopnia konsolidacji demokracji. Integracja staje się zatem katalizatorem i bodźcem dla wprowadzenia reform, sprzyjających osiaganiu standardów obowiązujących $\mathrm{w}$ skonsolidowanych demokracjach. W efekcie, Czarnogóra, dążąc do sprostania owym standardom, zmuszona jest do podejmowania nowych wyzwań i stałego doskonalenia wdrażanych rozwiązań. Dzięki temu możliwe jest w tym państwie funkcjonowanie wielu języków, kultur i religii przy jednoczesnym poszanowaniu praw i wolności obywatela. 